\title{
Mandarin Brazil: representações raciais dos chineses na sociedade brasileira
}

\section{Mandarin Brazil: racial representations of chinese in Brazilian society}

\author{
João Ítalo Silva \\ i Professor, Universidade do Estado de Minas Gerais. \\ Belo Horizonte - MG - Brasil \\ orcid.org/0000-0003-1548-2279 \\ joao_italo@hotmail.com
}

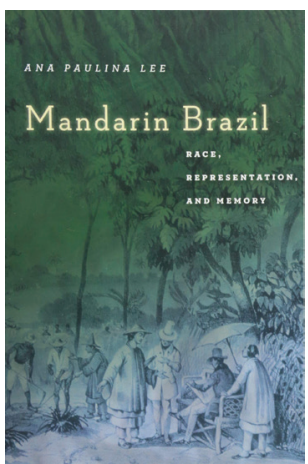

LEE, Ana Paulina. Mandarin Brazil: race, representation, and memory. Stanford: Stanford University Press. 2018. 256p.
A obra Mandarin Brazil, premiada como melhor livro em humanidades na seção Brasil pela Latin American Studies Association, é uma leitura importante para a compreensão das representações dos chineses na cultura popular brasileira. O livro remonta a construção e ressignificação dos estereótipos raciais associados ao imigrante chinês na literatura, na música e no teatro nos séculos XIX e XX. A obra extrapola o enfoque da historiografia nacional sobre os debates e as construções raciais em torno da imigração chinesa entre 1850 e 1890. Ana Paulina Lee (2018) priorizou a elaboração, reprodução e apropriação da chinesness, expressões culturais que elaboram conceitos e estigmas raciais referentes à China e aos seus habitantes. Essas imagens foram concebidas e apropriadas em meio a um intenso diálogo global fortalecido após a abolição do tráfico negreiro. Tais representações circulam dentro de uma memória circum-oceânica, um processo criativo por meio do qual a cultura da modernidade se inventa ao transmitir um passado que pode ser esquecido, recriado ou transformado em uma memória coletiva.

Mandarin Brazil é composto por seis capítulos, introdução e conclusão. A divisão do livro respeita a lógica das fontes e uma coerência cronológica. O primeiro capítulo introduz a relação Portugal/Brasil e China, sendo o único que não analisa um aspecto específico do universo cultural/social/político brasileiro. A noção de chinesness fica mais clara ao leitor no capítulo seguinte, onde ocorre a contextualização da discussão acerca da imigração chinesa no século XIX dentro da noção de perigo amarelo, isto é, a ameaça que a imigração de asiáticos traria para a composição racial e para a soberania nacional. A chinesness contribui para a definição de negritude e branquitude e a compreensão da identidade nacional a partir do olhar do outro. Os demais capítulos do livro levam o leitor a compreender o alcance do discurso racializado antichinês na cultura nacional nos livros de Machado de Assis, 
nas caricaturas de Angelo Agostini, nas personagens do teatro de revista do século XIX, nos textos ficcionais escritos por diplomáticos e nas músicas de Ari Barroso. O caminho cuidadosamente traçado pela pesquisadora permite a identificação dos discursos raciais em diferentes expressões da vida cultural e política brasileira ao longo dos séculos XIX e XX.

A diversidade dos documentos analisados revela a penetração das categorias raciais nas diferentes camadas da sociedade. A pesquisadora trabalhou com a análise de porcelanas, relatos de viagem, caricaturas, teatro de revista, literatura, poesia, música, marchas de carnaval e grafites. A diversidade das fontes permite a reconstrução da trajetória da chinesness em diferentes canais de expressão cultural. O receio da competição desleal entre o trabalhador chinês e o nacional, amplamente discutido por políticos e pensadores nos EUA e no Brasil no século XIX, estava presente, por exemplo, em canções de Ari Barroso e João de Barro durante o governo Getúlio Vargas. A autora entendeu a circulação dessas visões como uma memória circum-oceânica compartilhada e realimentada por várias sociedades em diferentes momentos. Os registros culturais reunidos revelam a longevidade e o vigor de conceitos de chinesness elaborados no século XIX. Os intelectuais da época do Império temiam que a mão de obra coolie, de origem asiática e etnicamente indesejada, ocupasse o lugar do trabalhador nacional e comprometesse a formação de um Brasil branco e eugênico. Esse receio perdurou por décadas.

Em outros momentos, a estudiosa analisa minuciosamente textos apenas citados por outros historiadores. Este é o caso da peça de teatro $O$ mandarim, escrita por Arthur de Azevedo e Sampaio Moreira e encenada em 1883. O enredo revela uma riqueza de críticas, imagens, representações e preconceitos raciais em torno do chinês, personificado em três figuras: o vendedor de camarão, o mandarim e a sua esposa. Representava-se dessa forma a pobreza extrema do trabalhador chinês, a dificuldade de assimilação da elite governante e a moral duvidosa das mulheres. Os trabalhadores asiáticos não resolveriam os problemas nacionais e ainda criariam outras questões. O receio da miscigenação ficou claro em Fritzmac, peça escrita por Arthur de Azevedo em parceria com o seu ilustre irmão Aluísio de Azevedo. A prole resultante da mistura de brasileiros e chineses foi representada como preguiçosa, suja e viciada em ópio e em álcool.

O teatro de Arthur de Azevedo foi categorizado como yellowface, performance que reflete estruturas sociais e dinâmicas de poder que integram o imaginário acerca das populações de origem asiática. Há um diálogo com a concepção do blackface nos EUA e os paralelos traçados contribuem para que o leitor perceba os canais que levaram o debate de acadêmico a outras camadas da sociedade. Tanto a peça de teatro supracitada quanto canções dos anos 1960 reproduzem a sexualidade chinesa como inadequada, bizarra e ameaçadora. O homem é retratado como afeminado, impotente e imoral, enquanto as mulheres seriam pequenas, infantis e exóticas. Essas concepções em torno dos chineses estiveram presentes no debate acerca da imigração europeia na segunda metade do século XIX. Nas músicas e no teatro, essas acepções ganharam um apelo popular e ficaram mais palpáveis à sociedade como um todo.

As personagens do teatro de revista apresentadas pela autora revelam algumas concepções dos chineses extremamente acessíveis ao público geral, não necessariamente escolarizado. Os discursos raciais ganham novas roupagens e tornam-se acessíveis a uma quantidade 
maior de pessoas. As fontes escolhidas pela autora distinguem a obra de outros textos sobre a imigração chinesa, por vezes restritos aos estudos de discursos parlamentares, notícias de jornais, panfletos, ensaios e opúsculos. A diversificação do corpus documental traz uma nova perspectiva e inspira estudos críticos e aprofundados que percebam as permanências, releituras e ressignificações da chinesness na cultura brasileira para além da questão chinesa discutida no século XIX.

\section{REFERÊNCIAS}

LEE, Ana Paulina.

Mandarin in Brazil: race, representation, and memory. Stanford: Stanford University Press. 2018.

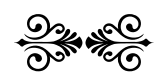

